\title{
The Effect of Learning English (L2) on Learning of Arabic Literacy (L1) in the Primary School
}

\author{
Abdelaziz M. Hussien ${ }^{1}$ \\ ${ }^{1}$ Department of Curriculum \& Instruction, Faculty of Education, Suez Canal University, Ismailia, Egypt \\ Correspondence: Abdelaziz M. Hussien, Department of Curriculum \& Instruction, Faculty of Education, Suez \\ Canal University, Ismailia, Egypt. E-mail: damhussien@gmail.com
}

Received: January 7, 2014 Accepted: February 8, 2014 Online Published: February 25, 2014

doi:10.5539/ies.v7n3p88 URL: http://dx.doi.org/10.5539/ies.v7n3p88

\begin{abstract}
This study investigated the effect of learning English (L2) on learning to read and spell connected texts accurately in Arabic (L1). The author selected a sample of 83 (38 males and 45 females; 45 bilinguals and 38 monolinguals) native Arabic-speaking fourth-graders in Egypt. Students completed the author-developed Oral Reading Accuracy Measure and Spelling Accuracy Measure. Interestingly, results revealed that the bilingual (Arabic-English) students performed better than their monolingual (Arabic) counterparts on the two literacy variables: oral reading accuracy (ORA) and spelling accuracy (SA). The discussion concludes that learning English (L2) has a positive effect on students' oral reading accuracy and spelling accuracy in Arabic (L1).
\end{abstract}

Keywords: multi-competence, bilingual education, Arabic literacy, oral reading accuracy, spelling accuracy

\section{Introduction}

Learning a second language is an indispensible aspect of the present life and thus, becomes a prevailing focus of many education systems worldwide. The bilingual education, the context of the current study, raises key questions that address bidirectional influences between two languages: the first language (L1) and the second language (L2). In this vein, many researchers pursue the impact that L1 has on L2 (e.g., Akamatsu, 1999; Figueredo, 2006; Hu, 2013; Kim, 2009; Saji \& Imai, 2013; Schwartz, 2013; Schwartz, Leikin, \& Share, 2005; Schwartz, Share, Leikin, \& Kozminsky, 2007). Others highlight the influence of L2 on learning of L1 (e.g., Balcom, 2003; Cook, 2002, 2003; Hussien, 2014a; Kecskes, 2010; Mennen, 2004; Noor, 2007; Yelland, Pollard, \& Mercuri, 1993; Zampini \& Green, 2001). In addition, some researchers compare between literacy processes e.g., phonological awareness, of L1 and L2 (e.g., Geva \& Seigel, 2000; Netten, Droop, \& Verhoeven, 2011; Saiegh-Haddad, Kogan, \& Walters, 2010; Wilcox, Yagelski, \& Yu, 2013). Above all, the notion of cross-linguistic transfer of literacy strategies between L1 and L2 has been highlighted by many researchers (e.g., Abu-Rabia \& Sammour, 2013; Durgunoglu, 2002; Ghuma, 2011; Leider, Proctor, Silverman, \& Harring, 2013; Saiegh-Haddad \& Geva, 2010; Treffers-Daller \& Sakel, 2012; Zhang et al., 2010). Taken together,

the bidirectional influence between languages is a developmental phenomenon. The L2 $\rightarrow \mathrm{L} 1 \mathrm{effect}$ significantly differs from the L1 $\rightarrow$ L2 effect, since L2 influence is cognitive and pragmatic rather than syntactic or lexical (Kecskes, 2010, p. 34).

In reality, there is a common belief, in the Egyptian context, that learning a second language, usually English, in the primary school negatively influences learning the mother tongue language, Arabic. The current study examined the validity of this critical issue which has been scarcely investigated in Arabic. The purposes of the current study were (a) to clarify the impact that English (L2) had on learning to read and spell connected texts accurately in Arabic (L1), and (b) to explain the differences between the fourth grade students' profiles of oral reading accuracy and spelling accuracy in Arabic.

\subsection{The Impact of L2 on Learning Literacy of L1}

In the second language acquisition (SLA), Cook $(1991,1994,2007)$ proposes the notion of multi-competence which highlights that the mind of someone who knows more than one language is different from the mind of a 
monolingual. The argument has been made that language proficiency and cognitive development in the mind of a bilingual student is positively influenced by learning a second language (Cook, 2002, 2003; Kecskes, 2008, 2010; Lauchlan, Parisi, \& Fadda, 2013). In other words, learning of L2 affects learning of L1 (e.g., Balcom, 2003; Mennen, 2004; Zampini \& Green, 2001), and learning of L1 is improved by learning of L2 (Cook, 2003). Learning Italian (L2) to English children enhanced their reading in English (L1) (Yelland et al., 1993), and Hungarian secondary school students who learn L2 performed better in writing essays in their L1 (Kecskes \& Papp, 2000). Further, university students learning English (L2) performed better than their monolingual counterparts in syntactic processing in Arabic (L1) (Noor, 2007). The current study clarified the impact of English (L2) on learning to read and spell connected texts accurately in Arabic (L1), which has been scarcely investigated.

\subsection{The Orthography of Arabic and English}

A critical issue rises in this context that is how English (L2) affects learning of literacy in Arabic (L1). To explain this issue it is important to consider the nature of orthography of Arabic and English. Despite the fact that Arabic and English are alphabetic orthographies, there are main differences between the two writing systems (Taouk \& Coltheart, 2004, pp. 30-33). Arabic is written and read from right to left while English is written and read from left to right. Unlike English, letters in Arabic take different shapes, though the main form is maintained, according to their position in a word (Hussien, 2014a, p. 75). In contrast to heterotrophic English orthography, Arabic is a homographic orthography, if presented unvowelized (Abu-Rabia \& Siegel, 1995, 2003; Taouk \& Coltheart, 2004, pp. 30-33). While English is a deep orthography (Geva \& Seigel, 2000, p. 3), pointing system and vowelization move Arabic from being shallow to deep. It is a shallow and transparent, if vowelized, and is a deep and opaque, if unvowelized. Vowels show the equivocal pronunciation, meaning and function of a word in a sentence (Abu Rabia, 1998, pp. 105-106; Taouk \& Coltheart, 2004, p. 31). Thus, word decoding is not simply an autonomous process like English rather it is a holistic process that requires processing of letters and vowels, visible or guessed, disambiguating identical forms of a word, the phenomenon of homograph, and recognizing changes of vowelization of the end of a word, the inflection process, according to its function in a sentence (Abu-Rabia, 1998, p. 107; Hussien, 2014b). Another critical difference is that Arabic, in contrast to English, is a consistent orthography that has predictable sound-letter and letter-sound conformities (Abu-Hajaj, 2006; Abu-Rabia, 1997, 2001; Abu-Rabia \& Siegel, 1995; Lervåg \& Hulme, 2010; Mahfoudhi, Everatt, \& Elbeheri, 2011; Taibah \& Haynes, 2011) whereas, English has less consistent orthography (Seymour, Aro, \& Erskine, 2003; Venezky, 1970, p. 11) e.g., buy and by. Further, Arabic is a diglossic language (Ferguson, 1959) with significant differences between literary and spoken language. Vernaculars are everyday language and literary or Standard Arabic (SA) is used in printed media, medium of instruction, and for formal use (Abu-Rabia, 2000; Maamouri, 1998; Taha, 2013, p. 721; Tahan, Cline, \& Messaoud-Galusi, 2011; Taouk \& Coltheart, 2004, pp. 32-33; Versteegh, 2001). This diglossic situation affects learning to read and write in Arabic (Abu-Rabia \& Taha, 2004; Saiegh-Haddad, 2003, 2004). Above all, the marker phenomenon (Venezky, 1970, p. 55), some letters are written but not pronounced, is more frequent in English than in Arabic (Abu-Rabia, 1998, p. 107).

\subsection{Learning to Read and Spell in Arabic}

Oral reading accuracy (ORA) is an important variable of oral reading fluency (Hussien, 2014), and it influences reading comprehension (Spooner, Baddeley, \& Gathercole, 2004). ORA refers to the extent to which children read aloud connected texts according to the letter-sound conventions in Arabic (Hussien, 2014a, p. 76, 2014b, p. 61). ORA in Arabic is a cognitively demanding process that requires children to disambiguate homographs, if text is introduced unvowelized, and to differentiate changes at the end of a word as an indication of its function / رحب محمدٌ بضيوفه

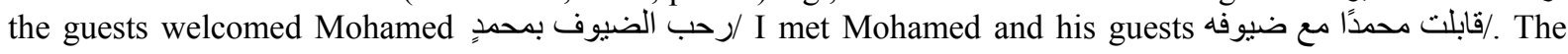
argument has been made that ORA, in Arabic, is not simply an autonomous process, like English, it is a holistic process that entails phonological, morphological, syntactic, and contextual processes (Abu-Rabia, 1998). Further, ORA is concerned with letter-sound conventions whereas spelling accuracy (SA) focuses on sound-letter conventions which makes SA a more cognitively demanding process than ORA (Abu-Rabia \& Taha, 2004, p.654).

Meta-analysis research (e.g., Bangert-Drowns, Hurley, \& Wilkinson, 2004; Graham, Gillespie, \& McKeown, 2013; Graham \& Hebert, 2011; Graham \& Perin, 2007) shows that teaching spelling and sentence construction enhance primary school students' (Grades 1-5) word reading and reading fluency. Scripts from different subjects and genres are more comprehensible when students (Grades 2-12) write about the content of what they read. In addition, increasing how much students write influences their reading comprehension. Writing is a complex process that involves learning to write and writing to learn (Graham, Gillespie, \& McKeown, 2013, p. 1). In 
learning to write, spelling accuracy (SA) is a significant variable in improving the quality of written expression (Puranik \& Al Otaiba, 2012), and in promoting kindergarteners' composition fluency (Kent, Wanzek, Petscher, Al Otaiba, \& Kim, 2013). SA, in the current study, refers to the extent to which students write words in connected texts according to sound-letter conventions in Arabic. In the literature, spelling errors negatively affect perception of students' writing ability (Kreiner, Schnakenberg, Green, Costello, \& McLin, 2002), and impede comprehension of written scripts (National Assessment Governing Board [NAGB], 2010, p. 78). In addition, Wilcox, Yagelski and Yu (2013) highlight spelling errors as the most common errors that negatively influence the message that the writer intends in L1 and L2 in different subject matters i.e., English language and social studies. Further, word spelling and reading contribute to writing quality of L1 and L2 of primary school students (Babayigit, 2013).The issue here is that what does the profile of oral reading accuracy and spelling accuracy tell us? In this context, "spelling errors can be informative about the aspects of the orthographic system that pose the greatest difficulties for developing spellers" (Protopapas, Fakou, Drakopoulou, Skaloumbakas, \& Mouzaki, 2013, p. 640).

\subsection{Context}

This study was conducted in two Egyptian primary public schools: a monolingual (Arabic) and a bilingual school (Arabic-English). All children are native Arabic-speaking. Both monolingual and bilingual schools teach the same subject matters as public schools though the bilingual schools teach English (L2) and use it as a carrier of academic development to teach Mathematics and Science as well. This context raised a critical issue that is the effect of the bilingual education, Arabic-English, on learning to read and spell in the first language, Arabic. In other words, whether learning and using English (L2) affect students' oral reading accuracy and spelling accuracy in Arabic (L1) or not. Especially, there is a common belief in the Egyptian context that learning a second language, usually English, in the primary schools negatively influences learning to read and write in Arabic (L1).

\section{Questions of the Study}

The current study pursued the following questions:

- What is the effect of English (L2) on oral reading accuracy in Arabic (L1)?

- What is the effect of English (L2) on spelling accuracy in Arabic (L1)?

- What is the profile of oral reading accuracy and spelling accuracy of the fourth grade students in Arabic?

\section{Method}

\subsection{Participants}

A purposeful sample of 83 (38 males and 45 females; 45 bilinguals and 38 monolinguals) Arabic-speaking fourth-graders was selected from Ismailia education district in Egypt. Children were selected from two public primary schools: a monolingual school $(\mathrm{M}=116$ months, $\mathrm{SD}=2.3)$ and a dual language school $(\mathrm{M}=118$ months, $\mathrm{SD}=1.6$ ). In the monolingual school, Arabic is the medium of instruction and in the dual language school Arabic and English are used as the medium of instruction. The two types of school teach Arabic as a national and a mother tongue language of all students. All students in the monolingual and dual language school study the same subject matters but, the dual language school teaches English (L2) and uses it as a carrier of academic development to teach Mathematics and Science as well. Further, it is well-established that socioeconomic status (SES) significantly influences language proficiency and cognitive development (e.g., Bradley \& Corwyn, 2002; Hart \& Risley, 1995; Hoff, Laursen, \& Tardif, 2002; Kieffer, 2012; Mercy \& Steelman, 1982; Schiff \& Ravid, 2012). Thus, a questionnaire was used to control SES of students' parents i.e., education, income, and occupation. An informed consent form was collected in writing from parents, the education district and the schools where the sample was selected. In addition, an oral consent was obtained from children.

\subsection{Measures and Procedures}

\subsubsection{Spelling Accuracy Measure (SAM)}

The researcher developed the Spelling Accuracy Measure (SAM). It is an oral dictation spelling measure that assesses the degree of spelling accuracy in Arabic. It consists of an informational excerpt (64 words). This excerpt was taken from a reading textbook developed by the Ministry of Education (2012) for the fourth-grade students in Saudi Arabia, and therefore it is expected to be an age-appropriate excerpt. Children had not been exposed to this excerpt. The researcher made sure that SAM is a valid and a reliable measure by distributing it to five experts in the field of teaching Arabic and requesting them to check the clarity of the measure. In addition, 
the researcher applied the SAM to a pilot sample (18 bilinguals and 16 monolinguals) and calculated reliability using Split-half $=0.90$ which indicates that SAM is a reliable measure. The SAM was administered in one single session by the researcher. The researcher read aloud, from the teacher's version, clearly and slowly and requested students to write down, in the students' sheets, what they hear from him. The researcher collected the students' sheets, marked words that are written incorrectly, and wrote down the number of errors each student made.

\subsubsection{Oral Reading Accuracy Measure (ORAM)}

The researcher also developed the Oral Reading Accuracy Measure (ORAM). It measures the degree of oral reading accuracy in Arabic. It consists of a vowelized informational excerpt (138 words). This excerpt was taken from a reading textbook developed by the Ministry of Education (2012) for the fourth-grade students in Saudi Arabia, and therefore this excerpt is expected to be readable independently by the students. Children had not been exposed to this excerpt. Validity and reliability of the measure were conducted. The researcher requested five experts in the field of teaching Arabic to check the clarity of the measure. In addition, the researcher applied the ORAM to a pilot sample (18 bilinguals and 16 monolinguals) and calculated reliability using Split-half $=$ 0.93 which indicates that ORAM is a reliable measure. The ORAM was also administered in one single session by the researcher. Each student was tested individually. A student was requested to read aloud the passage, from the student's version, and the researcher marked words, in the teacher's version, that are read incorrectly and wrote down the number of errors each student made.

\subsection{Analyses}

Descriptive statistics were conducted to explain children's profile of spelling accuracy and oral reading accuracy. In addition, an Independent-Samples T Test analysis was performed to compare between the scores of spelling accuracy for the bilingual and monolingual students. It was also performed to compare between the scores of oral reading accuracy for the bilingual and monolingual children as well.

\section{Results}

Pursuing the first question "What is the effect of English (L2) on oral reading accuracy in Arabic (L1)?" An Independent-Samples $\mathrm{T}$ Test analysis was conducted to compare between the scores of oral reading accuracy for the bilingual (Arabic-English) and monolingual (Arabic) students as depicted in Table 1.

Table 1. An Independent-Samples T Test analysis of the bilingual and monolingual students' oral reading accuracy

\begin{tabular}{lllllll}
\hline Variables & Students & $\mathrm{N}$ & $\mathrm{M}$ & $\mathrm{SD}$ & $\mathrm{T}$ & Sig. \\
\hline Oral reading accuracy & Bilinguals & 45 & 1.3 & 1 & 13.872 & .000 \\
& Monolinguals & 38 & 8.9 & 3 & & \\
\hline p
\end{tabular}

Note: $\overline{\mathrm{p}<.05}$.

Table 1 shows that there is a significant difference in the scores of oral reading accuracy for the bilingual students $(\mathrm{M}=1.3, \mathrm{SD}=1)$ and their monolingual counterparts $(\mathrm{M}=8.9, \mathrm{SD}=3), \mathrm{t}(81)=13.872, \mathrm{p}=.000$. These results suggest that learning English (L2) significantly influences learning to read in Arabic (L1). The results explain that the bilingual students made less oral reading errors than the monolingual students.

Addressing the second question "What is the effect of English (L2) on spelling accuracy in Arabic (L1)?" An Independent-Samples T Test analysis was performed to compare between the scores of spelling accuracy for the bilingual and monolingual students as explained in Table 2 .

Table 2. An Independent-Samples T Test analysis of the bilingual and monolingual students' spelling accuracy

\begin{tabular}{lllllll}
\hline Variables & Students & $\mathrm{N}$ & $\mathrm{M}$ & $\mathrm{SD}$ & $\mathrm{T}$ & Sig. \\
\hline Spelling accuracy & Bilinguals & 45 & 7.9 & 4.7 & 3.308 & .001 \\
& Monolinguals & 38 & 12.6 & 7.9 & & \\
\hline
\end{tabular}

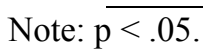


Table 2 indicates that there is a significant difference in the scores of spelling accuracy for the bilingual students $(\mathrm{M}=7.9, \mathrm{SD}=4.7)$ and their monolingual counterparts $(\mathrm{M}=12.6, \mathrm{SD}=7.9), \mathrm{t}(81)=3.308, \mathrm{p}=.001$. These results suggest that learning English (L2) positively affects learning to spell in Arabic (L1). The results show that the bilingual students made less spelling errors than the monolingual students.

Answering the third and last question "What is the profile of oral reading accuracy and spelling accuracy of the fourth grade students in Arabic?" Descriptive statistics were conducted to explain the children's profile of oral reading accuracy and spelling accuracy as indicated in Figure 1.

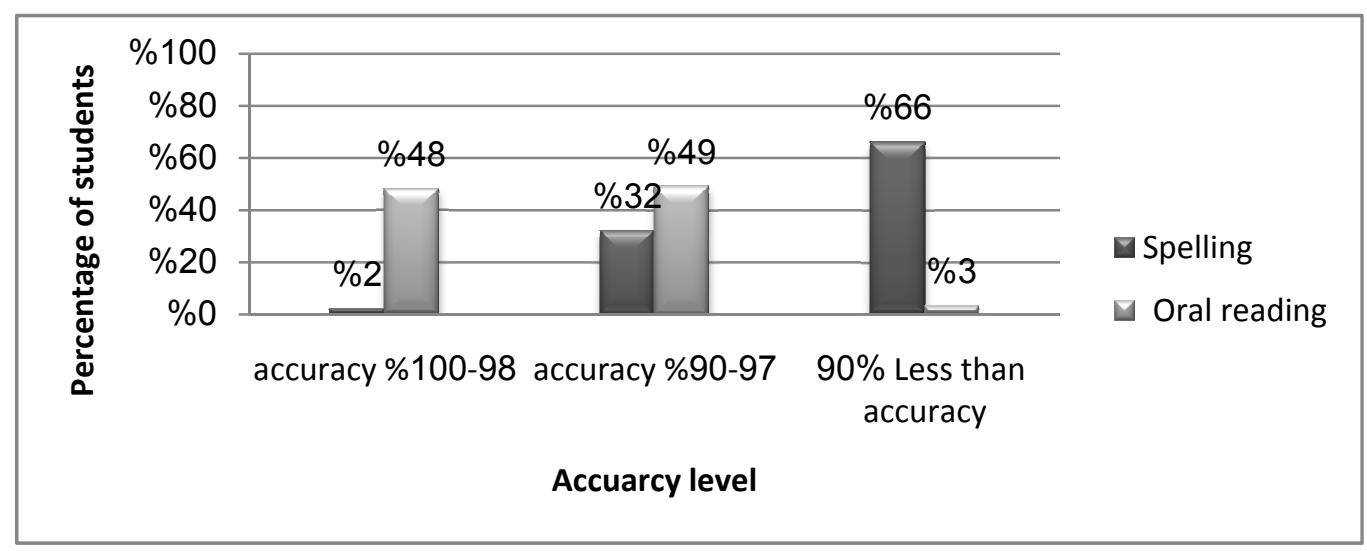

Figure 1. Accuracy level of oral reading and spelling

Figure 1 implies that the students performed better in oral reading accuracy than in spelling accuracy. Nearly a half of students $(48 \%)$ read the excerpt (138 words) independently with $98-100 \%$ accuracy and the other half (49\%) read at the expected instructional level. In contrast, two thirds of students (66\%) wrote the excerpt (64 words) with less than $90 \%$ accuracy and only $2 \%$ of students wrote with $98-100 \%$ accuracy.

\section{Discussion}

The first main findings of the current study are that the bilingual students (Arabic-English) performed better than their monolingual (Arabic) counterparts on oral reading accuracy and spelling accuracy measures. This result is congruent with previous research, learning of L2 helps with the ability to read (Hussien, 2014a; Yelland et al., 1993), and to write (Kecskes \& Papp, 2000) in L1. Bilingual children (Russian-Hebrew) performed better than monolinguals (Hebrew, a Semitic orthography like Arabic) on word reading accuracy (Schwartz, Share, Leikin, \& Kozminsky, 2007). In Arabic, Noor (2007) explains that university students who learn English (L2) showed better performance in syntactic processing in Arabic (L1) than their monolingual counterparts. The positive influence of English (L2) on learning to read and spell connected texts accurately in Arabic (L1) in the current study can be explained by the notion of multi-competence that was proposed by Cook and his colleagues. The argument has been made that the mind of someone who knows more than one language is different from the mind of a monolingual, as mentioned above. The issue here is that how learning of English (L2) affects learning to read and spell in Arabic (L1)? In fact, learning of L2 reorganizes and restructures linguistic system and affects cognitive development in the L2 learner's mind (Cook, 2002, 2003; Kecskes, 2010) which results in improvement of the L2 learner's language use (Kecskes, 2008, p. 34). In this vein, Leij, Bekebrede, and Kotterink (2010) postulate that the concurrent instruction in Dutch and English has positive effects on the acquisition of English (L2) and Dutch (L1).

In addition, another possible explanation of the current results is that the notion of cross-linguistic transfer of literacy processes between two languages (e.g., Cho, Chiu, \& McBride-Chang, 2011; Koda, 1993; Kong, 2006). In this vein, Ghuma (2011, pp. 210-212) explains that reading processes e.g., morphological and syntactic processing, can be transferred between English (L2) and Arabic (L1) and vice versa. In addition, Saiegh-Haddad and Geva (2008), and Farran, Bingham and Matthews (2012) postulate a cross-linguistic transfer between English (L1) and Arabic (L2), that is, phonological awareness in a given language predicts word reading in the other language while morphological awareness in the two languages is not correlated which indicates that morphological awareness is primarily a language-specific process. This idea of cross-linguistic transfer may explain why the bilingual students performed better than the monolingual students on spelling accuracy and oral 
reading accuracy. Further research is needed to investigate in depth how the idea of cross-linguistic transfer of literacy processes between English (L2) and Arabic (L1) influences learning to read and write in Arabic.

Above all, the current results are coupled with previous research (e.g., Genesee, Paradis, \& Cargo, 2004; Ryu, 2004; Seung-Yoeun \& Sookhee, 2006) suggests that learning dual language in early age improves bilingual students' language performance in L1 and L2. Therefore, these results challenge the common belief among Egyptian about the negative effects of learning L2, usually English, on learning to read and write in Arabic (L1) in the primary school. Essa and El-Mutawa (1998) postulate that there is no negative effect of learning English (L2) on learning of Arabic (L1) in the primary school. To conclude, learning English (L2) has positive effects on learning to read aloud and to spell connected scripts accurately in Arabic (L1). Noteworthy, Kecskes (2008, p. 34) postulates that positive effects of L2 on L1 is potential but not necessary. According to Kecskes these beneficial effects are possible if exposure to L1 is intensive and maintained and carefully planned. Teaching Arabic (L1) in the dual language school or bilingual schools in Egypt, the context of the current study, is intensive and maintained as a mother tongue of all students and English (L2) is also used as a carrier of academic development to teach Science and Mathematics in addition to teaching English as a subject matter as well. This supports the current results regard the positive effects of L2 (English) on L1 (Arabic).

The second and last findings of the current study are that the students performed better on oral reading accuracy than on spelling accuracy. A plausible explanation of these results is that "the spelling process demands awareness of orthographic units more than the reading process" (Abu-Rabia \& Taha, 2004, p. 654). In this vein, Taha (2013) explains that

phonological similarity between the emphatic and the non emphatic phonemes produces difficulties in spelling words that include one emphatic phoneme or more. A result of this difficulty can be inaccuracy in spelling. This spelling inaccuracy can manifest as phonetic errors (...). Therefore, spelling words that contain those emphatics requires a specific familiarity with the word's orthographic pattern and demands intensive cognitive resources (p. 723)

In the same vein, Abu-Rabia and Taha (2006) indicate that phonetic errors were dominant types of spelling errors in Arabic from grades 1 to 9. These errors also were more prevalent in Arabic than in English "as a result of poor knowledge of spelling rules as well as substitution between the emphatic consonants and their plain counterparts" (Abu-Rabi \& Sammour, 2013, p. 66) e.g., the phoneme $b / t^{5} /$ considered as emphatic phoneme to the soft phoneme $ت / t /$. Therefore, Abu-Rabia and Taha (2004) propose a dual model to diminish spelling errors in Arabic. This model proposes two routes: mapping sounds to letters explicitly (phonological route) to spell new unfamiliar words and using the spelling conventions (lexicon route) to spell familiar words. Another possible explanation is that the linguistic distance between spoken and Standard Arabic (diglossia), has an effect on learning to read and spell in Arabic. This diglossic situation negatively influences the phonological representations and hence the phonological awareness that contributes to reading and spelling acquisition (Saiegh-Haddad, 2003, 2004). To conclude, learning to spell is a more cognitively demanding process than learning to read in Arabic and spelling errors are attributed to and influenced by the uniqueness characteristics of the orthography of Arabic. "Reading and spelling in Arabic as literacy skills are affected by the specific linguistic and orthographic features of the language" (Taha, 2013, p. 726).

\section{Conclusion}

The current study adds to the literature with respect to positive effects of English (L2) on learning to read and spell connected texts accurately in Arabic (L1). It also explains the profile of oral reading accuracy and spelling accuracy in Arabic of the fourth grade students. The current results are coupled with previous research suggesting that learning dual language improves bilingual students' language performance in L1. Therefore, these results challenge the common belief among Egyptian about the negative effects of learning L2, usually English, on learning to read and write in Arabic (L1) in the primary school. Further research is needed to investigate in depth how the idea of cross-linguistic transfer of literacy processes between English (L2) and Arabic (L1) influences learning to read and write in Arabic and to explain which literacy processes are universal and which are language-specific. 


\section{Acknowledgments}

I would like to thank my colleagues Mrs. Abeer Al Areeny and Mrs. Heba Saeed, Suez Canal University, for their help in conducting the fieldwork. My sincere gratitude goes to my inspiring wife, Enas Abdelgelil, for her constant encouragement and patience.

\section{References}

Abu-hajaj, A. Z. (2006). معدل السرعة في القراءة لاى بعض الطالبات في مر احل التعليم العام والجامعي [Reading rate of female students in the general and university education]. Journal of Reading and Literacy, 61, 130-170.

Abu-Rabia, S. (1997). The need for cross-cultural considerations in reading theory: The effects of Arabic sentence context in skilled and poor readers. Journal of Research in Reading, 20(2), 137-147. http://dx.doi.org/10.1111/1467-9817.00026

Abu-Rabia, S. (1998). Reading Arabic texts: Effects of text type, reader type and vowelization. Reading and Writing: An Interdisciplinary Journal, 10(2), 105-119. http://dx.doi.org/10.1023/A:1007906222227

Abu-Rabia, S. (2000). Effects of exposure to literary Arabic on reading comprehension in a diglossic situation. Reading and Writing: An Interdisciplinary Journal, 13(1-2), 147-157. http://dx.doi.org/10.1023/A:1008133701024

Abu-Rabia, S. (2001). The role of vowels in reading semantic scripts: Data from Arabic and Hebrew. Reading and Writing: An Interdisciplinary Journal, 14(1-2), 39-59. http://dx.doi.org/10.1023/A:1008147606320

Abu-Rabia, S., \& Sammour, R. (2013). Spelling errors' analysis of regular and dyslexic bilingual Arabic-English students. Open Journal of Modern Linguistics, 3(1), 58-68. http://dx.doi.org/10.4236/ojml.2013.31007

Abu-Rabia, S., \& Siegel, L. S. (1995). Different orthographies, different context effects: The effects of Arabic sentence context on skilled and poor readers. Reading Psychology, 16(1), 1-19. http://dx.doi.org/10.1080/0270271950160101

Abu-Rabia, S., \& Siegel, L. S. (2003). Reading skills in three orthographies: The case of trilingual Arabic-Hebrew-English-speaking Arab children. Reading and Writing: An Interdisciplinary Journal, 16(7), 611-634. http://dx.doi.org/10.1023/A:1025838029204

Abu-Rabia, S., \& Taha, H. (2004). Reading and spelling error analysis of native Arabic dyslexic readers. Reading and Writing: An Interdisciplinary Journal, 17(7-8), 651-690. http://dx.doi.org/10.1007/s11145-004-2657-x

Akamatsu, N. (1999). The effects of first language orthographic features on word recognition processing in English as a second language. Reading and Writing: An Interdisciplinary Journal, 11(4), 381-403. http://dx.doi.org/10.1023/A:1008053520326

Babayigit, S. (2013). Contributions of word-level and verbal skills to written expression: comparison of learners who speak English as a first (L1) and second language (L2). Reading and Writing: An Interdisciplinary Journal (Online First Article). http://dx.doi.org/10.1007/s11145-013-9482-z

Balcom, P. (2003). Cross-linguistic influence of L2 English on middle constructions in L1 French. In V. J. Cook (Ed.), Effects of the second language on the first (pp. 168-192). Clevedon: Multilingual Matters Ltd.

Bangert-Drowns, R. L., Hurley, M. M., \& Wilkinson, B. (2004). The effects of school-based Writing-to-Learn interventions on academic achievement: A meta-analysis. Review of Educational Research, 74(1), 29-58. http://dx.doi.org/10.3102/00346543074001029

Cho, J. R., Chiu, M. M., \& McBride-Chang, C. (2011). Morphological awareness, phonological awareness, and literacy development in Korean and English: A 2-year longitudinal study. Scientific Studies of Reading, 15(5), 383-408. http://dx.doi.org/10.1080/10888438.2010.487143

Cook, V. J. (1991). The poverty-of-the-stimulus argument and multi-competence. Second Language Research, 7(2), 103-117. http://dx.doi.org/10.1177/026765839100700203

Cook, V. J. (1994). The metaphor of access to universal grammar. In N. Ellis (Ed.), Implicit learning and language (pp. 477-502). London: Academic Press.

Cook, V. J. (2007). Multi-competence: Black-hole or worm-hole for second language acquisition research. In Z. Han (Ed.), Understanding second language process (pp. 16-26). Clevedon: Multilingual Matters Ltd.

Cook, V. J. (Ed.). (2002). Portraits of the L2 user. Clevedon: Multilingual Matters Ltd. 
Cook, V. J. (Ed.). (2003). Effects of the second language on the first. Clevedon: Multilingual Matters Ltd.

De Angelis, G. (2005). Interlanguage transfer of function words. Language Learning, 55(3), 379-414. http://dx.doi.org/ 10.1111/j.0023-8333.2005.00310.x

Durgunoglu, A. Y. (2002). Cross-linguistic transfer in literacy development and implications for language learners. Annals of Dyslexia, 52(1), 189-204. http://dx.doi.org/10.1007/s11881-002-0012-y

Essa, M. R., \& El-Mutawa, N. A. (1998). أثر إخال مادة اللغة الإنجليزية على تدريس اللغة العربية لتلاميذ المرحلة الابتدائية [The effect of introducing English as a second language on learning of Arabic for primary school students]. Educational Journal, 46(12). 113-147.

Farran, L. K., Bingham, G. E., \& Matthews, M. W. (2012). The relationship between language and reading in bilingual English-Arabic children. Reading and Writing: An Interdisciplinary Journal, 25(9), 2153-2181. http://dx.doi.org/10.1007/s11145-011-9352-5

Ferguson, C. A. (1959). Diglossia. Word, 15, 325-340.

Figueredo, L. (2006). Using the known to chart the unknown: A review of first-language influence on the development of English-as-a-second-language spelling skill. Reading and Writing: An Interdisciplinary Journal, 19(8), 873-905. http://dx.doi.org/10.1007/s11145-006-9014-1

Genesee, R., Paradis, J., \& Cargo, M. B. (2004). Dual language development of disorder: A handbook on bilingualism and second language learning. Baltimore: Paul H. Brookes.

Geva, E., \& Seigel, L. S. (2000). Orthographic and cognitive factors in the concurrent development of basic reading skills in two languages. Reading and Writing: An Interdisciplinary Journal, 12(1-2), 1-30. http://dx.doi.org/10.1023/A:1008017710115

Ghuma, M. (2011). The transferability of reading strategies between L1 (Arabic) and L2 (English) (Published doctoral thesis, Durham University, UK). Retrieved from http://etheses.dur.ac.uk/924/

Graham, S., \& Hebert, M. (2011). Writing-to-read: A meta-analysis of the impact of writing and writing instruction on reading. Harvard Educational Review, 81, 710-744.

Graham, S., \& Perin, D. (2007). A meta-analysis of writing instruction for adolescent students. Journal of Educational Psychology, 99(3), 445-476. http://dx.doi.org/10.1037/0022-0663.99.3.445

Graham, S., Gillespie, A., \& McKeown, D. (2013). Writing: Importance, development, and instruction. Reading and Writing: An Interdisciplinary Journal, 26(1), 1-15. http://dx.doi.org/10.1007/s11145-012-9395-2

$\mathrm{Hu}, \mathrm{C} . \mathrm{F}$. (2013). Predictors of reading in children with Chinese as a first language: A developmental and cross-linguistic perspective. Reading and Writing: An Interdisciplinary Journal, 26(2), 163-187. http://dx.doi.org/ 10.1007/s11145-012-9360-0

Hussien, A. M. (2014a). The indicating factors of oral reading fluency of monolingual and bilingual children in Egypt. International Education Studies, 7(2), 75-90. http://dx.doi.org/10.5539/ies.v7n2p75

Hussien, A. M. (2014b). Reading Arabic Shallow and Deep Genres: Indispensible Variables to Science of Reading. Journal of Education and Learning, 3(1), 60-69. http://dx.doi.org/10.5539/jel.v3n1p60

Kecskes, I. (2008). The effect of the second language on the first language: The dual language approach. Babylonia, 2, 31-34. http://www.albany.edu/ ik692/files/babyloniaproofkecskes.pdf

Kecskes, I. (2010). Dual and multilanguage systems. International Journal of Multilingualism, 7(2), 91-109. http://dx.doi.org/10.1080/14790710903288313

Kecskes, I., \& Papp, T. (2000). Foreign language and mother tongue. Mahwah, NJ: Lawrence Erlbaum Associates.

Kent, S., Wanzek, J., Petscher, Y., Al Qtaiba, S., \& Kim, Y. S. (2013). Writing fluency and quality in kindergarten and first grade: The role of attention, reading, transcription, and oral language. Reading and Writing: An interdisciplinary Journal (Online First Articles). http://dx.doi.org/10.1007/s11145-013-9480-1

Kieffer, M. J. (2012). Before and after third grade: Longitudinal evidence for the shifting role of socioeconomic status in reading growth. Reading and Writing: An interdisciplinary Journal, 25(7), 1725-1746. http://dx.doi.org/10.1007/s11145-011-9339-2

Kim, Y. S. (2009). Cross linguistic influence on phonological awareness for Korean-English bilingual children. Reading and Writing: An interdisciplinary Journal, 22(7), 843-861. 
http://dx.doi.org/10.1007/s11145-008-9132-z

Koda, K. (1993). Transferred L1 strategies and L2 syntactic structure in L2 sentence comprehension. The Modern Language Journal, 77(4), 490-500. http://dx.doi.org/ 10.1111/j.1540-4781.1993.tb01997.x

Kreiner, D. S., Schnakenberg, S. D., Green, A. G., Costello, M. J., \& McLin, A. F. (2002). Effects of spelling errors on the perceptions of writers. Journal of General Psychology, 129(1), 5-17. http://dx.doi.org/10.1080/00221300209602029

Lauchlan, F., Parisi, M., \& Fadda, R. (2013). Bilingualism in Sardinia and Scotland: Exploring the cognitive benefits of speaking a minority language. International Journal of Bilingualism, 17(1), 43-56. http://dx.doi.org/10.1177/1367006911429622

Leider, C. M., Proctor, C. P., Silverman, R. D., \& Harring, J. R. (2013). Examining the role of vocabulary depth, cross-linguistic transfer, and types of reading measures on the reading comprehension of Latino bilinguals in elementary school. Reading and Writing: An interdisciplinary Journal, 26(9), 1459-1485. http://dx.doi.org/10.1007/s11145-013-9427-6

Leij, A. V., Bekebrede, J., \& Kotterink, M. (2010). Acquiring reading and vocabulary in Dutch and English: The effect of concurrent instruction. Reading and Writing: An interdisciplinary Journal, 23(3-4), 415-434. http://dx.doi.org/ 10.1007/s11145-009-9207-5

Lervåg, A., \& Hulme, C. (2010). Predicting the growth of early spelling skills: Are there heterogeneous developmental trajectories? Scientific Studies of Reading, 14(6), 485-513. http://dx.doi.org/10.1080/10888431003623488

Maamouri, M. (1998). Language education and human development: Arabic diglossia and its impact on the quality of education in the Arab region. Paper Presented at the Mediterranean Development Forum of the World Bank, Marrakech, Morocco, September, 3-6. Retrieved June 24, 2010, from http://www.eric.ed.gov

Mahfoudhi, A., Everatt, J., \& Elbeheri, G. (2011). Introduction to the special issue on literacy in Arabic [Special issue]. Reading and Writing: An Interdisciplinary Journal, 24(9), 1011-1018. http://dx.doi.org/10.1007/s11145-011-9306-y

Mennen, I. (2004). Bi-directional interference in the intonation of Dutch speakers of Greek. Journal of Phonetics, 32(4), 543-563. http://dx.doi.org/10.1016/j.wocn.2004.02.002

National Assessment Governing Board U.S., Department of Education. (2010). Writing framework for the 2011 National Assessment of Educational Progress. Retrieved December 24, 2013, from http://files.eric.ed.gov/fulltext/ ED512552.pdf

Netten, A., Droop, M., \& Verhoeven, L. (2011). Predictors of reading literacy for first and second language learners. Reading and Writing: An interdisciplinary Journal, 24(4), 413-425. http://dx.doi.org/10.1007/s11145-010-9234-2

Noor, H. H. (2007). The influence of L2 on the syntactic processing of L1 by Arab EFL learners. Journal of Literature, Language and Linguistics, 1(1), 1-18.

Protopapas, A., Fakou, A., Drakopoulou, S., Skaloumbakas, C., \& Mouzaki, A. (2013). What do spelling errors tell us? Classification and analysis of errors made by Greek schoolchildren with and without dyslexia. Reading and Writing: An Interdisciplinary Journal, 26(5), 615-646. http://dx.doi.org/10.1007/s11145-012-9378-3

Puranik, C. S., \& Al Otaiba, S. (2012). Examining the contribution of handwriting and spelling to written expression in kindergarten children. Reading and Writing: An Interdisciplinary Journal, 25(7), 1523-1546. http://dx.doi.org/10.1007/s11145-011-9331-x

Ryu, J. (2004). The social adjustment of three, young, high-achieving Korean-English bilingual students in kindergarten. Early Childhood Education Journal, 32(3), 165-171.

Saiegh-Haddad, E. (2003). Linguistic distance and initial reading acquisition: The case of Arabic diglossia. Applied Psycholinguistics, 24(3), 431-451. http://dx.doi.org/10.1017/S0142716403000225

Saiegh-Haddad, E. (2004). The impact of phonemic and lexical distance on the phonological analysis of word and pseudowords in a diglossic context. Applied Psycholinguistics, 25(4), 495-512. http://dx.doi.org/10.1017/S0142716404001249

Saiegh-Haddad, E., \& Geva, E. (2008). Morphological awareness, phonological awareness, and reading in 
English-Arabic bilingual children. Reading and Writing: An Interdisciplinary Journal, 21(5), 481-504. http://dx.doi.org/10.1007/s11145-007-9074-x

Saiegh-Haddad, E., \& Geva, E. (2010). Acquiring reading in two languages: An introduction to the special issue [Special issue]. Reading and Writing: An interdisciplinary Journal, 23(3-4), 263-267. http://dx.doi.org/10.1007/s11145-009-9208-4

Saiegh-Haddad, E., Kogan, N., \& Walters, J. (2010). Universal and language-specific constraints on phonemic awareness: Evidence from Russian-Hebrew bilingual children. Reading and Writing: An interdisciplinary Journal, 23(3-4), 359-384. http://dx.doi.org/10.1007/s11145-009-9204-8

Saji, N., \& Imai, M. (2013). Evolution of verb meanings in children and L2 adult learners through reorganization of an entire semantic domain: The case of Chinese carry/hold verbs. Scientific Studies of Reading, 17(1), 71-88. http://dx.doi.org/ 10.1080/10888438.2012.689788

Schiff, R., \& Ravid, D. (2012). Linguistic processing in Hebrew-speaking children from low and high SES backgrounds. Reading and Writing: An interdisciplinary Journal, 25(6), 1427-1448. http://dx.doi.org/10.1007/s11145-011-9326-7

Schwartz, M. (2013). The impact of the first language first model on vocabulary development among preschool bilingual children. Reading and Writing: An interdisciplinary Journal (Online First Articles). http://dx.doi.org/10.1007/s11145-013-9463-2

Schwartz, M., Leikin, M., \& Share, D. L. (2005). Bi-literate bilingualism versus mono-literate bilingualism: A longitudinal study of reading acquisition in Hebrew (L2) among Russian-speaking (L1) children [Special issue]. Written Language and Literacy, 8(2), 179-207.

Schwartz, M., Share, D., Leikin, M., \& Kozminsky, E. (2007). On the benefits of bi-literacy: Just a head start in reading or specific orthographic insights? Reading and Writing: An interdisciplinary Journal, 21(9), 905-927. http://dx.doi.org/ 10.1007/s11145-007-9097-3

Seung-Yoeun, Y., \& Sookhee, L. (2006). Mother brand English as an effective approach to teach English for young children as a foreign language in Korea. Reading Improvement, 43(40), 185-193.

Seymour, P. H. K., Aro, M., \& Erskine, J. M. (2003). Foundation literacy acquisition in European orthographies. British Journal of Psychology, 94(2), 143-174. http://dx.doi.org/10.1348/000712603321661859

Taha, H. Y. (2013). Reading and spelling in Arabic: Linguistic and orthographic complexity. Theory and Practice in Language Studies, 3(5), 721-727. http://dx.doi.org/10.4304/tpls.3.5.721-727

Tahan, S., Cline, T., \& Messaoud-Galusi, S. (2011). The relationship between language dominance and pre-reading skills in young bilingual children in Egypt [Special issue]. Reading and Writing: An Interdisciplinary Journal, 24(9), 1061-1087. http://dx.doi.org/10.1007/s11145-011-9301-3

Taibah, N. J., \& Haynes, C. W. (2011). Contributions of phonological processing skills to reading skills in Arabic speaking children [Special issue]. Reading and Writing: An Interdisciplinary Journal, 24(9), 1019-1042. http://dx.doi.org/10.1007/s11145-010-9273-8

Taouka, M., \& Coltheart, M. (2004). The cognitive processes involved in learning to read in Arabic. Reading and Writing: An Interdisciplinary Journal, $17(1-2), \quad$ 27-57. http://dx.doi.org/10.1023/B:READ.0000013831.91795.ec

Treffers-Daller, J., \& Sakel, J. (2012). Why transfer is a key aspect of language use and processing in bilinguals and L2-users. International Journal of Bilingualism, 16(1), 3-10. http://dx.doi.org/1367006911403206

Venezky, R. L. (1970). The structure of English orthography. The Hague-Paris: Mouton.

Versteegh, K. (2001). The Arabic language. Edinburgh: Edinburgh University Press.

Wilcox, K. C., Yagelski, R., \& Yu, F. (2013). The nature of error in adolescent student writing. Reading and Writing: An Interdisciplinary Journal (Online First Articles). http://dx.doi.org/10.1007/s11145-013-9492-x

Yelland, G. W., Pollard, J., \& Mercuri, A. (1993). The metalinguistic benefits of limited contact with a second language. Applied Psycholinguistics, 14(4), 423-444. http://dx.doi.org/10.1017/S0142716400010687

Zampini, M. L., \& Green, K. P. (2001). The voicing contrast in English and Spanish: The relationship between perception and production. In J. L. Nicol (Ed.), One mind, two languages: Bilingual language processing (pp. 23-48). Oxford: Blackwell Publishers Ltd.

Zhang, J., Anderson, R. C., Li, H., Dong, Q., Wu, X., \& Zhang, Y. (2010). Cross-language transfer of insight 
into the structure of compound words. Reading and Writing: An Interdisciplinary Journal, 23(3-4), 311-336. http://dx.doi.org/10.1007/s11145-009-9205-7

\section{Copyrights}

Copyright for this article is retained by the author(s), with first publication rights granted to the journal.

This is an open-access article distributed under the terms and conditions of the Creative Commons Attribution license (http://creativecommons.org/licenses/by/3.0/). 